\section{Iranian EFL learners' attitudes towards using pre- vs. post-questioning techniques in the comprehension of nonfiction texts}

\author{
Ghazyani, Aylar
}

Department of English Language Teaching, Gorgan Branch, Islamic Azad University, Gorgan, Iran (aylar.ghazyani@yahoo.com)

Jafari, Khadijeh $\bowtie$

Department of English Language Teaching, Gorgan Branch, Islamic Azad University, Gorgan, Iran (Khadijehjafari2002@yahoo.com)



ISSN: 2243-7754 Online ISSN: 2243-7762

OPEN ACCESS

$\begin{array}{lll}\text { Received: } 26 \text { January } 2016 & \text { Revised: } 15 \text { March } 2016 & \text { Accepted: } 27 \text { March } 2016\end{array}$

\title{
Abstract
}

Reading is one of the key sources of input for foreign and second language learners. Teachers therefore should use a set of useful strategies in order to help their students to develop a positive attitude toward reading. This study investigated Iranian EFL learners' attitudes towards the use of pre- and post-questioning techniques in their reading comprehension class. Thirty elementary EFL students studying English at Shokooh language institute in Gonbad-e Kāvus, Iran participated in this study. These students received pre- and post-questioning techniques (each class 15) in Autumn 2014-2015. The students' attitudes were examined by two independent Likert agree/disagree type teacher-made questionnaires. These questionnaires were designed to elicit the participants' attitudes towards the role of pre- and post-questioning techniques on their reading comprehension. Later, the results of the two questionnaires were analyzed using descriptive statistics. The results of these questionnaires clearly showed that the students in both groups completely recognized the advantages of using questioning techniques in their reading classes. Overall, students in both pre- and post-questioning groups had positive attitudes towards using such techniques in their reading comprehension classes. Some implications for EFL teachers and reading material developers in using strategies in reading classes are suggested at the end.

Keywords: pre-questioning; post-questioning; reading; comprehension; nonfiction texts 


\section{Iranian EFL learners' attitudes towards using pre- vs. post-questioning techniques in the comprehension of nonfiction texts}

\section{Introduction}

Reading is an important skill because it provides input for language learners, and also it develops the readers' knowledge in language (Strevens, 1977). According to Rivers (1981), "reading is the most important activity in any language class, not only as a source of information and a pleasurable activity, but also as a means of consolidating and extending one's knowledge of the language"( p. 259). Wixson and Peters (1984, p. 13) believe that "reading is the process of constructing meaning through the dynamic interaction among the reader's existing knowledge, the information suggested by the written language, and the context of the reading situation". Therefore reading can be considered as one of the most important skills in language learning, because the main purpose of reading skill is the act of reading for comprehension and for getting the meaning of the texts' writer (Grabe, 2002). According to Anderson (1999), reading is a key to achievement in all other language skills. EFL students in schools and universities often have problems in comprehending English texts. Difficult words, limited vocabulary, complicated sentences in the text, topic unfamiliarity, low motivation, low background knowledge, poor phonemic awareness, negative attitudes towards reading, and the teachers' use of inappropriate techniques in teaching reading are some factors that create such problems for the students in reading comprehension (Kasper, 1993; Aebersold \& Field, 1997). On the other hand, academic texts are different from non-academic ones and they belong to different genres with different features, i.e., nonfiction versus fiction texts, which may bring some difficulties for students in reading comprehension (Karami \& Salahshoor, 2014).

Therefore teachers should try to use innovative techniques to improve the students' motivation, comprehension, and develop positive attitudes towards reading by using different activities in pre-, while, and post-reading stages such as, teaching difficult/new words, using questioning techniques, group discussions, underlining, summary writings, and many other related activities. Questioning as a kind of teacher/learner interaction is one of these efficient techniques that may help students to use their background knowledge about the topic and eventually, this may improve their comprehension of the given text. Therefore by using this technique, not only the students may comprehend the text better, but also they would have positive attitudes toward reading. In this study, the researcher focused on EFL students' attitudes towards using pre- vs. postquestioning techniques in the comprehension of texts.

\section{Literature review}

Reading as Mason and Krashen (1997) state is an important skill, because this skill always provides students with practice, improvement, and modification. Chastain (1988) emphasized the importance of reading skill in language learning classes, in which four language skills have the same level of importance to lead the students toward the success. As "psycholinguistic model of reading" of Goodman (1967) states, reading is a selective process, in which the reader selects input on the basis of his/her expectations using available language cues, then decisions are made to be rejected, confirmed, or refined as reading progresses (Yoon, 2013).

According to Smith (1971) and Goodman (1967), the different views about the nature and the process of reading skill, lead to the emergence of different models in reading. Bottom-up model, as Gough (1972) explains, focuses mainly on the way that the readers get information from the printed text, according to this model the first things that readers deal with them in the text are letters, words, and then sentences in an organized manner. In top-down model, according to Goodman (1967), the reader's expectations in mind about the text according to his/her prior knowledge help to understand the meaning of the whole text.

Later Rumellhart (1977) and Stanovich (1980) suggested the interactive model as an interaction between 
Iranian EFL learners' attitudes towards using questioning techniques in the comprehension of nonfiction texts

bottom-up and top-down models. Therefore, a successful comprehension of the text requires interaction between bottom-up and top-down processing (Eskey, 1988). These two processes (bottom-up and top-down) can complete each other during reading process (Carrell, 1983). On the other hand, as Rumelhart (1980) states, schema theory explains how readers can use prior knowledge to comprehend the text. According to this theory, reading comprehension happens when the reader uses bottom-up and top-down processing simultaneously (Anderson, 1979).

According to Nunan (1991) using questioning technique in the class helps the teachers to create interest for the students and increase their focus and ability to think, also this technique helps the teachers to clarify the points for the students. Teachers may ask questions in the class to check the students' knowledge and understanding, to increase their students' capability of self-expression, or to force them to think deeply about the details of the text (Ur, 1991). Teachers' questions can motivate the students to predict, give explanations, and produce output; on the other hand, students' generated questions can help the students to understand the text better (Dillon, 1982). Therefore, questioning technique is a process which facilitates the teaching and learning process and its main purpose is to add the individual's knowledge and comprehension (Zenger \& Weldon, 1977). Among different classifications of question types, in the present study, the researcher used Long and Satos' (1983) display and referential questions. Furthermore, in this study the researcher focused on the role of the questions that teachers ask in the class to activate their students' background knowledge.

Beers (2003) suggests that, in order to help the readers to better understand the text, teachers can use reading strategies such as pre-reading, during reading, and post-reading activities. Regarding the role of prior knowledge and comprehension, Anderson and Pearson (1984) propose that, comprehension is affected by prior knowledge, it paves the way for the students to make inferences while reading, helps the students to identify the more important information presented in the text, and finally it creates a plan for students in order to recall the information as well as comprehending. Furthermore, according to Garner (1987) metacognition has an indispensible role in comprehension, as well. He states that activities such as planning how to approach a given learning task, monitoring comprehension, directing a mental process, and evaluating progress toward the completion of a task are metacognitive activities.

According to Harvey and Goudvis (2000) texts like novels that tell stories about the people or events are more understandable to readers, because readers can easily make connections between their experiences and those ideas in the story. On the other hand, Alexander and Jetton (1996) explain that nonfiction texts like textbooks, often include unfamiliar and scientific contents, so the readers' prior knowledge may not help them to understand the text. According to Duke and Tower (2004), there are five types of nonfiction texts: informational texts, biography, concept books, procedural texts, and reference materials. Alvermann and Phelps (2002) proposed that nonfiction texts are based on different structures such as cause and effect structure, the structure of questioning and answering, problem and solution structure, comparing and contrasting, listing structure, and the structure of sequencing of the events.

Wisendanger and Wollenberg (1978) have conducted a study in which they investigated the effect of pre-questioning on reading comprehension of L1 students. To do this research, 90 students were divided into two experimental groups and one control group. In EG one, the teacher used pre-questioning by inferential questions or high-order questions and for EG two, pre-questioning with factual questions or low-order questions were used. The results showed that both pre-questioning groups did better in reading comprehension, also in comparing the results of two experimental classes, the score of students in EG one (inferential pre-questioning group) were significantly higher than the score of students in EG two (factual pre-questioning group).

In a study, Tudor (1988) investigated the effect of two pre-reading activities on the text comprehension of L2 learners at three proficiency levels, answering pre-questions and providing text summary. He compared the results of the treatments (summarizing and pre-questioning) and finally he concluded that, both treatments improved comprehension for lower proficiency groups but not with the more advanced group. 
Ghazyani, A., \& Jafari, K.

Alemi and Ebadi (2010) conducted a research, in which they examined the effect of pre-reading activities on 40 Iranian university students. They compared three pre-reading activities (pre-questioning, pictorial context, and vocabulary pre-teaching) with a control condition. Students in the control group were taught using conventional teaching methods. They concluded that using pre-reading activities improved students' reading comprehension in the experimental groups. However, they did not explain which experimental group outperformed the other groups. Mihara (2011) also investigated the effects of two pre-reading strategies (pre-questioning and vocabulary pre-teaching) on Japanese EFL students' reading comprehension. The results of the study showed that pre-questioning strategy was more effective, also students with higher English proficiency level received better scores rather than lower level students, apart from their pre-reading strategy.

In another study, Thongyon and Chiramanee (2011) have investigated the effects of two pre-reading activities on 60 students' comprehension, in which guessing reading content from pictures and pre-questions were the treatments. After analyzing the gathered data, it was found that students in both treatments performed better in the post-test, the group which received guessing meaning from the pictures was more successful than the students in the pre-question group, and both groups were extremely pleased with the activity which they experienced. While, Hendra (2011) conducted a quasi-experimental research in which he examined the effect of pre-questioning on the students' reading comprehension achievement with 64 students in Jakarta. After treatment, the results of pre- and post-tests showed that the use of pre-questioning method highly improved the students reading comprehension ability.

An overview of the literature shows that previous studies mainly examined the effects of different types of pre-reading strategies using quantitative research designs; very few studies have examined EFL students' attitudes towards the effect of pre- and post-questioning activities on enhancing reading comprehension ability of EFL students. As a response to this gap, the present research examines EFL students' attitudes towards the use of pre- and post-questioning techniques in their reading class.

\section{Research Questions}

The research question of this study stated as:

Q1: What are Iranian elementary EFL student's attitudes on the use of pre- and post-questioning techniques in their reading comprehension class?

\section{Method}

\subsection{Participants}

The researcher used convenience sampling method to select the participants of the study. Thirty elementary EFL learners at Shokooh language institute in Gonbad-e Kāvus, Iran were the participants of the study, their average age was 16 and their first language was Persian. They have been studying English for more than 3 years. At the beginning of the study, the purpose and importance of the research were explained to the students.

\subsection{Materials}

In this study the following instruments were used:

$>$ Reading Passages: in order to make use of nonfiction texts, as the title of this study suggests, the researcher used ten nonfiction reading passages from the textbook, "Facts and Figures: Reading and Vocabulary Development", by Ackert and Lee (2004), 4th edition, to identify the role of pre- and post-questioning techniques on the learners' reading comprehension ability. This book which consists of seven units and five lessons in every unit is mostly comprised of reading comprehension of unfamiliar interesting nonfiction passages. From the seven units of this book, the researcher selected 
Iranian EFL learners' attitudes towards using questioning techniques in the comprehension of nonfiction texts

four units, by the name of unit 1) Animals, unit 2) How? Why?, unit 3) Plants, and unit 4) Exploration and Adventure. The researcher used four lessons from each three units and just two lessons from the fourth unit. Totally, fourteen reading texts were used for teaching.

Attitude Questionnaires: in order to elicit the participants' attitudes towards the role of pre- and post-questioning techniques on the comprehension of elementary EFL students, two Likert 5-point agree/disagree scale questionnaires were designed, one for pre-questioning class (18 items) and the other for post-questioning students (16 items).The researcher adapted the questionnaire from Thongyon and Chiramanees (2011); some items were modified according to the purpose of the study. In order to pilot these two questionnaires, the researcher asked 20 elementary students in her colleague's class to give their ideas about the items in the questionnaires. They answered to the questionnaire items by choosing number 1 for strongly disagree, 2 for disagree, 3 for neither agree nor disagree, 4 for agree, and 5 for strongly agree. After conducting the pilot test and performing the modifications, the items of the questionnaires were checked by the supervisor. The validity of the questionnaires was checked by two $\mathrm{PhD}$ holders and the supervisor. The Cronbach's alpha reliability of the questionnaires was 0.89 and 0.85 for pre-questioning and post-questioning questionnaires, respectively.

\subsection{Treatment Procedures}

$>$ In pre-questioning class, the teacher first wrote the title of the reading text on the board (e.g., The Dolphin), and then she asked some general questions related to the topic, the students answered the teachers' questions by using their prior knowledge. After pre-questioning stage, which lasted about 10 minutes, the teacher distributed the reading passages, (e.g., The Dolphin) to students. Then, students were asked to read the text silently and answer the comprehension questions followed by the text.

$>$ In post-questioning class, the teacher first distributed the reading texts, and then she asked the students to read the text silently. After reading, the teacher wrote the title of the text on the board, and then she asked some general questions related to the text, the students answered to their teachers' questions using the information presented in the text. After questioning/answering process which lasted 10 minutes, the teacher asked the students to answer the comprehension questions followed by the text. At the end of the study, the teacher administered the two attitude questionnaires in two classes in order to elicit the students' attitudes and feelings about the treatments that the teacher used in their classes. The students were asked to complete the questionnaires by reading items and selecting the one of the numbers from 1 to 5 , from "strongly disagreed" to "strongly agreed". To ensure full understanding of the items by the students, the questionnaires were translated into students' mother language.

\section{Results}

\subsection{Results of the Pre-questioning Questionnaire}

Generally, the students in the pre-questioning class had positive attitude towards the treatment. Their answers were analyzed and indicated in Table 1.

As shown in Table 1, a majority of the students (80\%) in pre-questioning class, strongly agreed that prequestioning technique made them more interested in reading and others (20\%) agreed. More than half of the students (53.3\%) strongly agreed that pre-questioning in reading made them curious about the text, among others $40 \%$ agreed and only $6.6 \%$ were undecided. $46.6 \%$ of the students strongly agreed that pre-questioning helped them to ask questions to themselves about the text, $40 \%$ agreed, and only $6.6 \%$ either were undecided or disagreed. A majority of the students $(66.6 \%)$ strongly agreed that pre-questioning helped them to understand the text better and others (33.3\%) also agreed. 


\section{Table 1}

The Percentage of the Students' Responses to the Items in Pre-questioning Attitude Questionnaire

\begin{tabular}{|c|c|c|c|c|c|}
\hline Opinion & SD & $\mathrm{D}$ & $\mathrm{N}$ & $\mathrm{A}$ & SA \\
\hline $\begin{array}{l}\text { 1. Pre-questioning in reading makes me more } \\
\text { interested in reading. }\end{array}$ & 0 & 0 & 0 & $20 \%$ & $80 \%$ \\
\hline $\begin{array}{l}\text { 2. Pre-questioning in reading makes me curious } \\
\text { about the text before reading. }\end{array}$ & 0 & 0 & $6.6 \%$ & $40 \%$ & $53.3 \%$ \\
\hline $\begin{array}{l}\text { 3. Pre-questioning in reading challenges me to ask } \\
\text { questions to myself about the text. }\end{array}$ & 0 & $6.6 \%$ & $6.6 \%$ & $40 \%$ & $46.6 \%$ \\
\hline $\begin{array}{l}\text { 4. Pre-questioning in reading helps me to } \\
\text { understand the text better. }\end{array}$ & 0 & 0 & 0 & $33.3 \%$ & $66.6 \%$ \\
\hline $\begin{array}{l}\text { 5. Pre-questioning in reading makes me more } \\
\text { confident to read and to answer post-reading } \\
\text { questions. }\end{array}$ & 0 & 0 & 0 & $6.6 \%$ & $93.3 \%$ \\
\hline $\begin{array}{l}\text { 6. Pre-questioning in reading gives me the } \\
\text { opportunity to think about the text and analyze it } \\
\text { better. }\end{array}$ & $6.6 \%$ & $3.3 \%$ & 0 & $40 \%$ & $50 \%$ \\
\hline $\begin{array}{l}\text { 7. Pre-questioning technique helps me to learn more } \\
\text { from sharing ideas with classmates. }\end{array}$ & 0 & 0 & $13.3 \%$ & $40 \%$ & $46.6 \%$ \\
\hline $\begin{array}{l}\text { 8. Pre-questioning in reading reduces my worry } \\
\text { about answering to reading comprehension } \\
\text { questions. }\end{array}$ & 0 & 0 & $6.6 \%$ & $26.6 \%$ & $66.6 \%$ \\
\hline $\begin{array}{l}\text { 9. Pre-questioning technique is fun and it makes me } \\
\text { happy with reading activity. }\end{array}$ & 0 & 0 & 0 & $40 \%$ & $60 \%$ \\
\hline $\begin{array}{l}\text { 10. Pre-questioning in reading makes the classroom } \\
\text { environment more enjoyable. }\end{array}$ & 0 & 0 & 0 & $33.3 \%$ & $66.6 \%$ \\
\hline $\begin{array}{l}\text { 11. Pre-questioning in reading makes me like } \\
\text { English more. }\end{array}$ & 0 & 0 & $6.6 \%$ & $33.3 \%$ & $60 \%$ \\
\hline $\begin{array}{l}\text { 12. Pre-questioning in reading helps me to read the } \\
\text { passages with specific purpose. }\end{array}$ & 0 & 0 & 0 & $33.3 \%$ & $66.6 \%$ \\
\hline $\begin{array}{l}\text { 13. Pre-questioning in reading helps me to guess } \\
\text { and learn the most important parts of the text. }\end{array}$ & 0 & 0 & 0 & $13.3 \%$ & $86.6 \%$ \\
\hline $\begin{array}{l}\text { 14. Pre questioning in reading helps me to connect } \\
\text { the text information with my prior knowledge. }\end{array}$ & 0 & 0 & 0 & $6.6 \%$ & $93.9 \%$ \\
\hline $\begin{array}{l}\text { 15. Pre-questioning in reading causes the text to } \\
\text { seem more attractive and purposeful to me. }\end{array}$ & 0 & 0 & 0 & $46.6 \%$ & $53.3 \%$ \\
\hline $\begin{array}{l}\text { 16. Pre-questioning technique gives me motivation } \\
\text { to read the text. }\end{array}$ & 0 & 0 & 0 & $26.6 \%$ & $73.3 \%$ \\
\hline $\begin{array}{l}\text { 17. Pre-questioning technique improves my reading } \\
\text { and understanding speed. }\end{array}$ & 0 & 0 & 0 & $40 \%$ & $60 \%$ \\
\hline $\begin{array}{l}\text { 18. Pre-questioning technique helps me to predict } \\
\text { the topic and the contents of the text before reading. }\end{array}$ & 0 & 0 & 0 & $20 \%$ & $80 \%$ \\
\hline
\end{tabular}

Note. SD: Strongly Disagree, D: Disagree, N: Neither agree nor disagree, A: Agree, SA: Strongly Agree

All participants $(93.3 \%)$ either strongly agreed or agreed $(6.6 \%)$ that pre-questioning made them more confident to read and to answer post-reading questions. Half of the class (50\%) strongly agreed that pre-questioning gave them the opportunity to think about the text and analyze it better, $40 \%$ agreed, $3.3 \%$ disagreed, and only $6.6 \%$ of the students strongly disagreed. $46.6 \%$ of the class strongly agreed that pre-questioning technique helped them to learn more from sharing ideas with classmates, $40 \%$ agreed and $13.3 \%$ were undecided. Majority of the participants (66.6\%) either strongly agreed or agreed (26.6\%) that prequestioning technique reduced their worry about answering to reading comprehension questions, only a small percentage of the participants $(6.6 \%)$ were undecided. All participants either strongly agreed $(60 \%)$ or agreed $(40 \%)$ that pre-questioning technique is fun and it made them happy with reading activity. $66.6 \%$ of the students strongly agreed that pre-questioning in reading made the classroom environment more enjoyable, and $33.3 \%$ agreed. $60 \%$ of the students strongly agreed that pre-questioning in reading made them like English more, $33.3 \%$ agreed, and only $6.6 \%$ were undecided. $66.6 \%$ of the class strongly agreed that pre-questioning in reading helped 
Iranian EFL learners' attitudes towards using questioning techniques in the comprehension of nonfiction texts

them to read the passages with specific purpose, and $33.3 \%$ agreed. $86.6 \%$ of the students strongly agreed that pre-questioning in reading helped them to guess and learn the most important parts of the text, and $13.3 \%$ agreed. Almost all of the class (93.9\%) strongly agreed that pre-questioning in reading helped them to connect the text information with their prior knowledge, and only $6.6 \%$ agreed. $53.3 \%$ of the students strongly agreed that prequestioning in reading caused the text to seem more attractive and purposeful to them, and $46.6 \%$ of them agreed. $73.3 \%$ of the class strongly agreed that pre-questioning technique gave them motivation to read the text, and $26.6 \%$ agreed. $60 \%$ of the students strongly agreed that pre-questioning technique improved their reading and understanding speed, and $40 \%$ agreed. $80 \%$ of the students strongly agreed that pre-questioning technique helped them to predict the topic and the contents of the text before reading and $20 \%$ agreed. As it was stated earlier, the questionnaire was given to the participants in post-questioning group, too. The results are given in table 2 .

\subsection{Results of the Post-questioning Questionnaire}

The students in the post-questioning class also had a positive attitude towards the treatment. The students' answers to the questionnaire in post-questioning class is analyzed and indicated in Table 2.

\section{Table 2}

The Percentage of the Students' Responses to the Items in Post-questioning Attitude Questionnaire

\begin{tabular}{|c|c|c|c|c|c|}
\hline Opinion & SD & $\mathrm{D}$ & $\mathrm{N}$ & $\mathrm{A}$ & SA \\
\hline $\begin{array}{l}\text { 1. Post-questioning in reading makes me more interested } \\
\text { in reading. }\end{array}$ & 0 & 0 & 0 & $26.6 \%$ & $73.3 \%$ \\
\hline $\begin{array}{l}\text { 2. Post-questioning activities make me to understand the } \\
\text { text more deeply. }\end{array}$ & 0 & 0 & 0 & $13.3 \%$ & $86.6 \%$ \\
\hline $\begin{array}{l}\text { 3. Post-questioning activities help me to notice to very } \\
\text { important/key points of the text. }\end{array}$ & 0 & 0 & 0 & $33.3 \%$ & $66.6 \%$ \\
\hline $\begin{array}{l}\text { 4. Post-questioning activities make the reading task more } \\
\text { purposeful to me. }\end{array}$ & 0 & 0 & $6.6 \%$ & $40 \%$ & $53.3 \%$ \\
\hline $\begin{array}{l}\text { 5. Post-questioning activities make me more confident } \\
\text { about what I understood from the text. }\end{array}$ & 0 & 0 & 0 & $26.6 \%$ & $73.3 \%$ \\
\hline $\begin{array}{l}\text { 6. Post-questioning activities help me to understand the } \\
\text { text more by critically analyzing what I have read. }\end{array}$ & 0 & 0 & $6.6 \%$ & $20 \%$ & $73.3 \%$ \\
\hline $\begin{array}{l}\text { 7. Post-questioning activities help me to do a deeper analysis } \\
\text { of the text I have already read. }\end{array}$ & 0 & 0 & 0 & $40 \%$ & $60 \%$ \\
\hline $\begin{array}{l}\text { 8. Post-questioning technique reduces my worry about } \\
\text { answering to reading comprehension questions. }\end{array}$ & 0 & 0 & 0 & $20 \%$ & $80 \%$ \\
\hline $\begin{array}{l}\text { 9. Post-questioning activities are fun and make me happy } \\
\text { with reading task. }\end{array}$ & 0 & 0 & $6.6 \%$ & $40 \%$ & $53.3 \%$ \\
\hline $\begin{array}{l}\text { 10.Post-questioning activities help me to make } \\
\text { interpretations of the text. }\end{array}$ & 0 & 0 & 0 & $20 \%$ & $80 \%$ \\
\hline $\begin{array}{l}\text { 11.Post-questioning technique improves my } \\
\text { comprehension ability. }\end{array}$ & 0 & 0 & 0 & $33.3 \%$ & $66.6 \%$ \\
\hline $\begin{array}{l}\text { 12. Post-questioning activities encourage me to seek } \\
\text { additional information about the topic from outside } \\
\text { sources. }\end{array}$ & 0 & 0 & 0 & $13.3 \%$ & $86.6 \%$ \\
\hline $\begin{array}{l}\text { 13. Post-questioning activities help me to summarize the } \\
\text { key points after I have done the reading. }\end{array}$ & 0 & 0 & $13.3 \%$ & $26.6 \%$ & $60 \%$ \\
\hline $\begin{array}{l}\text { 14. Post-questioning activities help me to check/evaluate } \\
\text { my comprehension of the text I have already read. }\end{array}$ & 0 & 0 & 0 & $6.6 \%$ & $93.9 \%$ \\
\hline $\begin{array}{l}\text { 15. Post-questioning activities give the reading } \\
\text { exercise/tasks a sense of meaning so that I feel I have } \\
\text { achieved/learned something. }\end{array}$ & 0 & 0 & $6.6 \%$ & $13.3 \%$ & $80 \%$ \\
\hline $\begin{array}{l}\text { 16. Post-questioning activities help me to do the reading } \\
\text { tasks/exercises easier. }\end{array}$ & 0 & 0 & 0 & $26.6 \%$ & $73.3 \%$ \\
\hline
\end{tabular}

As table 2 shows, more than half of the class (73.3\%) strongly agreed that post-questioning in reading made 
them more interested in reading and $26.6 \%$ agreed. $86.6 \%$ of the students strongly agreed that post-questioning activities made them to understand the text more deeply and $13.3 \%$ agreed. $66.6 \%$ of the class strongly agreed that post-questioning activities helped them to notice to very important/key points of the text and $33.3 \%$ agreed. $53.3 \%$ of the students strongly agreed that post-questioning activities made the reading task more purposeful to them, $40 \%$ agreed, and only $6.6 \%$ were undecided. $73.3 \%$ of the students strongly agreed that post-questioning activities made them more confident about what they understood from the text and $26.6 \%$ agreed. $73.3 \%$ of the class strongly agreed that post-questioning activities helped them to understand the text more by critically analyzing what they have read, $20 \%$ agreed, and only $6.6 \%$ were undecided. $60 \%$ of the students strongly agreed that post-questioning activities helped them to do a deeper analysis of the text that they have already read and $40 \%$ agreed.

A great number of the students $(80 \%)$ strongly agreed that post-questioning technique reduced their worry about answering to reading comprehension questions and $20 \%$ agreed. $53.3 \%$ of the class strongly agreed that post-questioning activities are fun and made them happy with reading task, $40 \%$ agreed, and only $6.6 \%$ were undecided. $80 \%$ of the students strongly agreed that post-questioning activities helped them to make interpretations of the text and $20 \%$ were undecided. $66.6 \%$ of the students strongly agreed that post-questioning technique improved their comprehension ability and $33.3 \%$ agreed. $86.6 \%$ of the students strongly agreed that post-questioning activities encouraged them to seek additional information about the topic from outside sources and $13.3 \%$ agreed. $60 \%$ of the class strongly agreed that post-questioning activities helped them to summarize the key points after they have done the reading, $26.6 \%$ agreed, and $13.3 \%$ were undecided. Almost all of the class $(93.9 \%)$ strongly agreed that post-questioning activities helped them to check/evaluate their comprehension of the text they have already read and $6.6 \%$ agreed. $80 \%$ of the students strongly agreed that post-questioning activities gave the reading exercise/tasks a sense of meaning so that they feel they have achieved/learned something, $13.3 \%$ agreed, and only $6.6 \%$ were undecided. $73.3 \%$ of the class strongly agreed that post-questioning activities helped them to do the reading tasks/exercises easier and $26.6 \%$ agreed.

\section{Discussion of the Findings}

According to the students' answers to the attitude questionnaires in pre-questioning class, $93.3 \%$ of the students believed that pre- questioning in reading helped them to connect the text information with their prior knowledge and also made them more confident to read and answer the post-reading questions. Moreover, almost most of the students in post questioning group (93.9\%), strongly agreed that these activities helped them to check their comprehension of the text that they have already read. Overall, the researcher found that the students had extremely positive attitudes towards using questioning techniques in teaching reading comprehension in both classes.

The findings of this research is in line with the findings of a study conducted by Thongyon and Chiramanee (2011) in which they concluded that the students had positive attitudes towards pre-reading activities. The results of this study confirmed the findings of Wisendanger and Wollenberg's (1978) study which showed the effect of pre-questioning on improving reading comprehension of L1 students. The present research also is in line with the findings of study which is conducted by Tudor (1988) in which they found that lower level proficiency students performed better after using pre-reading activities. This study's findings also support the findings of Alemi and Ebadis' (2010) study who concluded that using pre-reading activities improved students' comprehension. While, Post-questioning technique, on the other hand, allows students to find out if they understand every element of the taught material. The findings of the present study indicated that post-questioning technique can be considered as an essential instructional activity as the pre-questioning.

Overall, the findings of the present study indicated that the students in both classes had positive attitudes regarding their treatments. They believed pre- and post- questioning foster their comprehension of the reading texts, they also had more motivation for reading, and this increased motivation can lead to better performance. 
Iranian EFL learners' attitudes towards using questioning techniques in the comprehension of nonfiction texts

\subsection{Conclusions and Implication of the Study}

In general, according to the findings of this study, most of the learners showed their positive attitudes regarding using pre- and post- questioning techniques in their reading comprehension classes, and they believed that they comprehend the text better when the teacher applied those techniques in their reading classes. The findings of this study highlights the importance of using pre- and post-reading activities in EFL classes, teachers need to pay attention to using well-organized techniques in reading classes. According to the received feedback from the students in both classes at the end of the course, most of the learners were thankful for using these techniques in teaching reading, because they deeply realized that using questioning techniques improved their comprehension ability, and make the reading texts enjoyable and also purposeful for them. Hopefully, the results of this research can be useful for English language teachers, students, and also text book designers. They are suggested to incorporate different types of pre and post-reading activities into reading courses.

\section{References}

Ackert, P., \& Lee, L. (2004). Facts and figures (reading and vocabulary development) (4th ed). Language Teaching Publications.

Aebersold, J., \& Field, M. L. (1997). From reader to reading teacher: Issues and strategies for second language classrooms. Cambridge: Cambridge University Press.

Alemi, M., \& Ebadi, S. (2010). The effects of pre-reading activities on ESP reading comprehension. Journal of Language Teaching and Research, 1(5), 569-577. http://dx.doi.org/10.4304/jltr.1.5.569-577

Alexander, P. A., \& Jetton, T. L. (1996). The role of importance and interest in the processing of text. Educational Psychology Review, 8(1), 89-121. http://dx.doi.org/10.1007/BF01761832

Alvermann, D. E., \& Phelps, S. F. (2002). Content reading and literacy: Succeeding in today's diverse classrooms. Boston: Allyn and Bacon.

Anderson, N. (1999). Exploring second language reading: Issues and strategies. Boston, MA: Heinle\&Heinle. Anderson, T. H. (1979). Study skills and learning strategies. In H. F. O’Neil, Jr. \& C. D. Spielberger (Eds.), Cognitive and affective learning strategies (pp. 77-97). New York: Academic Press.

Anderson, R. C., \& Pearson, P. D. (1984). Aschema-theoretic view of basic processes in reading comprehension. In P. D. Pearson (Ed.), Handbook of reading research (pp. 255-292). New York: Longman.

Beers, K. (2003). When kids can't read, what teachers can do: A guide for teachers 6-12. Portsmouth: Heinemann.

Carrell, P. (1983). Some issues in studying the role of schemata, or background knowledge in second Language comprehension. Reading in a Foreign Language, 1(2), 81-92.

Chastain, K. (1988). Developing second language skills (3rd ed.). San Diego: Harcourt Brace Jovanovich, Inc.

Dillon, J. T. (1982). The multidisciplinary study of questioning. Journal of Educational Psychology, 74, 147-165. http://dx.doi.org/10.1037/0022-0663.74.2.147

Duke, N. K., \& Tower, C. (2004). Nonfiction texts for young readers. In J. Hoffman \& D. Schallert (Eds.), The texts in elementary classrooms (pp. 125-144). Mahwah, NJ: Erlbaum.

Eskey, D. E. (1988). Holding in bottom: An interactive approach to the language problems of second language readers. In D. Carrel, J. Devine, \& D. E. Eskey (Eds.), Interactive approaches to second language reading (pp. 73-92). New York: Cambridge University Press. http://dx.doi.org/10.1017/CBO9781139524513.011

Garner, R. (1987). Metacognition and reading comprehension. Norwood, NJ: Ablex.

Goodman, K. (1967). Psycholinguistic universals in the reading process. In P. Pimsleur \& T. Quinn (Eds.), The psychology of second language learning (pp. 135-142). Cambridge: Cambridge University Press.

Gough, P. (1972). One second of reading. In J. F. Kavavagh \& I. G. Mattingly (Eds.), Language by ear and by eye (pp. 331-358). Cambridge, Mass: MIT press.

Grabe, W. (2002). Reading in a second language. In R. B. Kaplan (Ed.), The Oxford handbook of applied linguistics (pp. 49-59). Oxford: Oxford University Press. 
Ghazyani, A., \& Jafari, K.

Harvey, S., \& Goudvis, A. (2000). Strategies that work: Teaching comprehension to enhance understanding. Portland, ME.: Stenhouse Publishers.

Hendra, A. (2011). The effects of pre-questioning on the reading comprehension achievement. Retrieved from http://repository.uinjkt.ac.id/dspace/handle/123456789/464

Karami, M., \& Salahshoor, F. (2014). The relative significance of lexical richness and syntactic complexity as predictors of academic reading performance. International Journal of Research Studies in Language Learning, 3(2), 17-28. http://dx.doi.org/10.5861/ijrsll.2013.477

Kasper, L. F. (1993). The keyword method and foreign language vocabulary learning: A rationale for its use. Foreign Language Annals, 26(2), 244-251. http://dx.doi.org/10.1111/j.1944-9720.1993.tb01172.x

Long, M, H., Sato, C. J. (1983). Classroom foreigner talk discourse: Forms and functions of teachers' questions. In H. W. Seliger \& M. H. Long (Eds.), Classroom oriented research in second language acquisition (pp. 3-34). Rowley, MA: Newbury House.

Mason, B., \& Krashen, S. (1997). Extensive reading in English as a foreign language. System, 25(1), 91-102. http://dx.doi.org/10.1016/S0346-251X(96)00063-2

Mihara K. (2011). Effects of pre-reading strategies on EFL/ESL reading comprehension. TESL Canada Journal, 28(2), 51-73. http://dx.doi.org/10.18806/tesl.v28i2.1072

Nunan, D. (1991). Language teaching methodology: A textbook for teachers. London: Prentice Hall.

Rivers, W. M. (1981). Teaching foreign-language skills (2nd ed.). Chicago: University of Chicago Press.

Rumelhart, D. (1980). Schemata: The building blocks of cognition. In R. Spiro, B. C. Bruce, \& W. F. Brewer (Eds.), Theoretical issues in comprehension (pp. 33-58). Hillsdale, NJ: Erlbaum.

Smith, F. (1971). Understanding reading: A psycholinguistic analysis of reading and learning to read. New York: Holt, Rinehart and Winston.

Stanovich, K. E. (1980). Toward an interactive- compensatory model of individual differences in the development of reading fluency. Reading Research Quarterly, 16(1), 32-71. http://dx.doi.org/10.2307/747348

Strevens, P. (1977). New orientations in the teaching of English. London: Oxford University Press.

Thongyon, P., \& Chiramanee, T. (2011). The effects of pre-reading activities on reading comprehension ability. Proceedings of the 3rd International Conference on Humanities and Social Sciences. Prince of Songkla University.

Tudor, L. (1988). A comparative study of the effect of two pre-reading formats on L2 reading comprehension. RELC Journal, 19(2), 71-86. http://dx.doi.org/10.1177/003368828801900206

Ur, P. (1991). A course in language teaching: Practice and theory. Cambridge: Cambridge University Press.

Wisendanger, K. D., \& WollenBerg, J. P. (1978). Pre questioning inhibits third graders' reading comprehension. Reading Teacher, 31(8), 892-895.

Wixson, K. K., \& Peters, C. W. (1984). Reading redefined: A Michigan Reading Association position paper. The Michigan Reading Journal, 17(1), 4-7.

Yoon, T. (2013). Beyond the traditional reading class: The application of an e-book in EFL English classroom, International Journal of Research Studies in Language Learning, 2(1), 17-26. http://dx.doi.org/10.5861/ijrsll.2012.93

Zenger, S. K., \& Weldon, F. Z. (1977). 57 Ways to teach (A quick reference for teachers). Los Angeles, California: Crescent Publication. 